\title{
Fatty Acid Compositions and Physicochemical Properties of Feta Cheese Made from Bovine Milk
}

\author{
S. Y. Park \\ Department of Food Industry Service, Cheonan Yonam College, Cheonan, Chungnam, Korea
우유로 제조한 휘타치즈의 지방산 조성과 물리화학적 특성 박승용

천안연암대학 외식산업과

요 약

우유로 제조한 휘타치즈의 지방산 조성과 숙성중 물리화학적 특성 변화를 연구하였다. 우유 휘타치 즈의 성분조성은 지방 $22.79 \%$, 단백질 $10.57 \%$, 수분 함량 $59.87 \%$ 이었다. $4{ }^{\circ} \mathrm{C}$ 에서 14 일간 치즈를 숙 성한 결과, 젓산균은 $\log \mathrm{CFU} / \mathrm{g}$ 의 값이 10.25 에서 7.95 로 감소하였으며, 치즈의 $\mathrm{pH}$ 는 $\mathrm{pH} 6.22$ 에서 $\mathrm{pH}$ 5.55 로 변하였다. 치즈의 색상은 L-value의 경우 92.5에서 100.1로 lightness가 증가하였으나, a-value는 -2.4 에서 4.6으로 red color가 강해졌으며, b-value는 8.3에서 -14.1로 gray color가 증가하였다. 조직특 성에 있어서 resilience는 저장기간에 따른 점진적 증가 $(\mathrm{p}<0.01)$ 가 인정되었으며, adhesiveness는 제조 직후 보다 증가 $(\mathrm{p}<0.01)$ 하였으나, 저장기간에 따른 차이는 없었다. Hardness, fracturability, gumminess와 chewiness는 $0{ }^{\circ} \mathrm{C}$ 저장온도에서 점차로 증가하였으나 통계적인 유의성은 인정되지 않았다. 14 일 숙성 된 우유 휘타치즈의 관능적 강도는 단맛, 우유취, 짠맛 등에서 대조치즈보다 훨씬 높았으며 $(\mathrm{p}<0.01)$ 저작감도 다소 높았다 $(\mathrm{p}<0.05)$. 관능적 기호도는 냄새, 색상, 입안느낌, 저작감을 제외한 관능적 특성 들이 숙성과 더불어 개선 $(\mathrm{p}<0.01)$ 되었다. 휘타치즈의 포화지방산 함량은 $52.61 \%$ 로서 불포화지방산 함량 $(47.39 \%)$ 보다 많았으며, 단일불포화지방산 함량이 $28.98 \%$ 로서 이중 또는 다가불포화지방산 함 량 $(18.41 \%)$ 보다 많았다. 영양적으로 중요성이 높은 $\omega 6$ 및 $\omega 3$ 지방산의 함량은 각각 $9.27 \%$ 및 $0.55 \%, \mathrm{CLA}$ 지방산 두 이성체 (c18:2c9t11 및 $\mathrm{c} 18: 2 \mathrm{t} 10 \mathrm{c} 12)$ 의 총 함량은 $0.11 \%$, arachidonic acid (c20:4) 함량은 $0.19 \%$, DHA 지방산 (c22:6n3) 함량은 $0.12 \%$ 이었다.

(Key words : Feta cheese, Nutritional compositions, Organoleptic properties, Textural properties, Fatty acid compositions)

\section{I . INTRODUCTION}

The principal white brined cheese variety, Feta, Telemes and Domiati are traditionally made around the eastern Mediterranean countries (Fox et al., 2000). The original characteristic features of the feta cheese is made from sheep milk or mixed sheep and goat milk at the ratio of less than $30 \%$, which yields a very white curd, and are now manufactured worldwide from cow milk in case of shortage of sheep milk and goat milk (Fox et al., 2000). For the purpose of preservation in high ambient temperatures, feta cheese is stored in a brine solution $(7 \sim 8 \%)$ leading to a high salt content (Robinson, 1995). The Greek government has made an effort to legislate the manufacturing procedure and quality standardization of traditional Greek feta type cheese made in small scale

Corresponding author : Department of Food Service Industry of Cheonan Yonam College, \#3-1, Soohyang-ri, Seonghwan-eup, Cheonan, Chungnam, Korea. 330-792,

Tel \& Fax : 82-41-580-1297, E-mail : sypark@yonam.ac.kr 
manufacturers in local areas of Greece. Such efforts lead to enthusiastic studies by academic institutions and R\&D centers in the cheese industry. Wium and Qvist, $\left(1997^{\mathrm{a}}\right)$ and Wium et al. $\left(1997^{\mathrm{b}}\right)$ studied the sensory texture profile analysis and rheological properties of UF-feta cheese by an axial compression and dynamic test. The effects of Ent. faecium FAIR-E 198 and 243 on the microbiological populations, physicochemical, and sensory characteristics of traditional Greek feta were studied by Sarantinopoulos et al. (2002). For the improvement of the flavour of low fat feta cheese, many studies were reported on the free fatty acids (Moatsou et al., 2004; Kandarakis et al., 2001; Georgala et al., 2005) and volatile compounds of low fat feta cheese made with a commercial adjunct culture (CR-213) (Kondyli et al., (2002) ; Katsiari et al., 2002). Recently, several studies have been carried out on the effect of adjunct culture on the aroma compounds of feta type cheese (Bintsis and Robinson, 2004), on the mechanism of lipolysis during aging (Haenlein, 2004), and on the microstructure (Wium, 2003).

In Korea, feta cheese made from caprine milk has recently begun small scale production by caprine milk manufacturers (Kim and Hur, 2001; Park and Kim, 2006). Only a few studies had been done on the compositions (Kim and Park, 2004), hypoallergenic and therapeutic significance (Park, 2000) of goat milk. A study on the nutritional, textural and organoleptic characteristics of feta cheese made from goat milk (Kang and Park, 2006) revealed that the sensory of caprine feta cheese was restrictive to Korean consumers owing to the strong goaty flavour. This study is carried out to evaluate the nutritional, textural and organoleptic characteristics and the fatty acid compositions of feta cheese made from bovine milk.

\section{MATERIALS \& METHODS}

\section{Manufacturing of feta cheese}

Bovine milk, produced at an experimental dairy farm at Cheonan Yonam College, was pasteurized for 30 sec. at $72^{\circ} \mathrm{C}$ without standardization of milk fat. A thermophillic starter culture, composed of Lactobacillus bulgaricus and Streptococcus thermophilus, was revived for $16 \mathrm{~h}$ in $10 \%$ reconstituted skim milk and inoculated to $100 \mathrm{~L}$ of bovine milk. Rennet solution (Naturen-290, Denmark) was added for making cheese curds. The coagulum formed after $30 \mathrm{~min}$ was cut using a set of curd knives into $1 \mathrm{~cm} \times 1 \mathrm{~cm}$ curd

Table 1. Manufacturing of feta cheese from bovine milk

\begin{tabular}{lcccc}
\hline Steps & Volume/ Weight & Duration Time & $\mathrm{TA}(\%) / \mathrm{pH}$ & Temperature \\
\hline \hline Milk & $100 \mathrm{~L}$ & - & $0.13 \% \mathrm{Milk}$ & $5^{\circ} \mathrm{C}$ \\
Pasteurization & - & $30 \mathrm{~min}$ & - & $63^{\circ} \mathrm{C}$ \\
Starter Culture & $2 \mathrm{~kg}$ & $40 \mathrm{~min}$ & $0.78 \%$ Culture & $34^{\circ} \mathrm{C}$ \\
Rennet & $3 \mathrm{~g}$ & $45 \mathrm{~min}$ & $0.16 \%$ Milk & $32^{\circ} \mathrm{C}$ \\
Curd Cutting & $1 \times 1 \mathrm{~cm}$ & $5 \mathrm{~min}$ & & - \\
Whey Drain & - & $30 \mathrm{~min}$ & $0.28 \%$ Whey & $30^{\circ} \mathrm{C}$ \\
Hooping & - & $240 \mathrm{~min}$ & $\mathrm{pH} 6.22$ & - \\
Brine Salting & $($ Salt $18 \%)$ & $120 \mathrm{~min}$ & - & $5^{\circ} \mathrm{C}$ \\
\hline
\end{tabular}

$\mathrm{TA}=$ Titratable acidity. 
cubes to expel whey and stirred gently for 30 min and then ladled into stainless strainers covered with linen cloth for $4 \mathrm{~h}$. The firmed curd mass was then cut into blocks $(15 \mathrm{~cm} \times 10$ $\mathrm{cm})$ and immersed into $18 \% \mathrm{NaCl}$ brine solution at $5^{\circ} \mathrm{C}$. After $2 \mathrm{~d}$ of brine salting, the cheese was stored for $14 \mathrm{~d}$ for aging in two cold rooms $\left(0^{\circ} \mathrm{C}\right.$ and $\left.4^{\circ} \mathrm{C}\right)$.

\section{Analytical methods}

The compositions of bovine milk and the ratio of casein to fat ( $\mathrm{CF}$ ratio) were analyzed using a Bentley 150 (Bentley Instruments, USA) after warming the milk sample in a water bath at $40^{\circ} \mathrm{C}$.

Moisture was obtained by the method of AOAC (1990) that $5 \mathrm{~g}$ of cheese was crushed by a mixer and $10 \mathrm{~g}$ of sea sands added to it. The samples were dried in a drying oven at $98^{\circ} \mathrm{C}$ for $2 \mathrm{~h}$. Cheese fat was determined by the method of AOAC (1990) that $5 \mathrm{~g}$ of cheese was put into a conical filter paper and covered with defatted cotton. The weights of cheese $\left(\mathrm{W}_{1}\right)$, conical filter paper $\left(\mathrm{W}_{2}\right)$, and defatted cotton $\left(\mathrm{W}_{3}\right)$ were then weighed. The samples were dried in a drying oven at $98^{\circ} \mathrm{C}$ for $12 \mathrm{~h}$ and the total weight $\left(\mathrm{W}_{4}\right)$ weighed. The extracted fat from the conical filter was put onto a siphone by flushing a stream of solvent $(100 \mathrm{ml} / 250 \mathrm{ml})$ through the filter. The flow rate of the solvent was controlled and extracted for $4 \mathrm{~h}$, and then the extracts were evaporated in a fume hood and dried in a drying oven at $98^{\circ} \mathrm{C}$ for $12 \mathrm{~h}$. The weight of dried fat was weighed $\left(\mathrm{W}_{5}\right)$ and the fat content was calculated as follows;

$\operatorname{Fat}(\%)=\frac{\mathrm{W}_{1} 4-\mathrm{W}_{1} 5}{\left(\mathrm{~W}_{1} 1+\mathrm{W}_{1} 2+\mathrm{W}_{1} 3\right)-\left(\mathrm{W}_{1} 1+\mathrm{W}_{1} 3\right)} \times 100$

Cheese protein was analyzed by the method of AOAC (1990) in which $1.5 \mathrm{~g}$ of the cheese sample prepared for moisture content was put into a tube and dried at $98^{\circ} \mathrm{C}$ for $3 \mathrm{~h}$. After drying, $12 \mathrm{ml}$ of $0.1 \mathrm{~N} \mathrm{HCl}$ and 2 drops of catalyst were added and attached to the preheated apparatus and heated at $550 \sim 600^{\circ} \mathrm{C}$ for $1.5 \mathrm{~h}$. Distilled water $(100 \mathrm{ml})$ was added to the cooled sample in order to dissolve the salt and boiled using the Kjeldahl apparatus after adding 40\% $\mathrm{NaOH}$. Nitrogen, in the form of ammonium hydroxide was collected in a container containing boric acid (0.1\% methyl red in ethanol : $0.1 \%$ bromocresol green in ethanol : $1 \%$ boric acid in distilled water and titrated with $0.1 \mathrm{~N} \mathrm{HCl}$. Crude protein was calculated using a conversion factor (6.38) as follows;

Crude protein $(\%)=\frac{\left(\mathrm{V}_{1}-\mathrm{V}_{2}\right) \times \mathrm{F} \times 6.38}{\mathrm{E}} \times 1400$

Here, $\left(\mathrm{V}_{1}\right)=0.1 \mathrm{~N} \mathrm{HCl}(\mathrm{mL})$ for sample; $\mathrm{V}_{2}=$ $0.1 \mathrm{~N} \mathrm{HCl}(\mathrm{mL})$ for blank; $\mathrm{F}=$ factor of $0.1 \mathrm{~N}$ $\mathrm{HCl}, \mathrm{E}=$ sample weight $(\mathrm{mg})$.

Ash content was measured by the method of AOAC(1990). NaCl was measured by the portable chloride detector (Salt meter, Ebro, USA). The $\mathrm{pH}$ of the cheese was measured by a $\mathrm{pH}$ meter (Model 5985-80, Cole Parameter Instrument, USA) after preparing a sample by homogenization of cheese $(10 \mathrm{~g})$ in $90 \mathrm{ml}$ of distilled water at $75,000 \mathrm{rpm}$. The color of the cheese was determined by exposing the cheese slices to ambient temperature for $15 \mathrm{~min}$ and measured by a Minolta Chromameter (Model CR 200, Ramsey, $\mathrm{NJ})$. CIE values of the standard plate were $\mathrm{L}^{*}=$ 96.34, $\mathrm{a}^{*}=0.18$ and $\mathrm{b}^{*}=1.92$.

Lactic acid bacteria was enumerated as follows; $1 \mathrm{~g}$ of cheese was suspended into $0.1 \%$ peptone solution and serially transferred into the MRS broth. The number of colonies formed on the MRS agar contained $0.02 \%$ sodium azide after cultivating at $37^{\circ} \mathrm{C}$ for $48 \mathrm{~h}$ was counted as the number of lactic acid bacteria.

Texture profiles were analyzed as follows; 4 $\mathrm{cm}$ of diameter of feta cheese was sliced and put it into a vinyl bag. The slice was heated in a water bath at $90^{\circ} \mathrm{C}$ for $1 \mathrm{~h}$ and then wrapped with wrap paper and kept in a refrigerator. The 
slice was cut by $2 \mathrm{~cm}$ height with a flat top and put on the sample holder to make it straight using the probe of XT-RA Texture Analyzer (Stable Micro System. UK). The texture profile was determined by the Texture profile analysis (TPA) program.

Table 2. Condition of parameters for texture profile analysis

\begin{tabular}{ll}
\hline Parameter & Condition \\
\hline \hline Option & TPA \\
Force Units & Grams \\
Strains & On \\
Pre Test Speed & $10.0 \mathrm{~mm} / \mathrm{s}$ \\
Test Speed & $1.0 \mathrm{~mm} / \mathrm{s}$ \\
Post Test Speed & $10.0 \mathrm{~mm} / \mathrm{s}$ \\
Strain & $60 \%$ \\
Time & 2 \\
Graph Type & 10 \\
\hline
\end{tabular}

For the analysis of free fatty acids, $10 \mathrm{~g}$ of the cheese was taken to extract the fat by Folch's solution (Chloroform: Met-OH = 2:1) containing BHT. The fat $(0.2 \mathrm{~g})$ was injected into a reflux tube with $10 \mathrm{ml}$ of $0.5 \mathrm{~N} \mathrm{NaOH}$ in Met-OH. Saponification was done by heating for $15 \mathrm{~min}$ and then methylalcohol containing $3 \mathrm{ml}$ of $\mathrm{BF}_{3}$ (14\%) was added. The injection sample for the GC analysis was prepared from the upper layer being formed after filling the saturated $\mathrm{NaCl}$ solution to the methylated sample, which was heated for $5 \mathrm{~min}$ after the addition of hexane $(5 \mathrm{ml})$.

Fatty acids were analyzed by the Hewlett Packard GC system (6890N series) equipped with a DBwax fused silica capillary column $(60 \mathrm{~m} \times 0.25 \mathrm{~mm}$
I.D., 0.25 um film thickness) and detected by an FID detector. The analysis conditions for GC set a linear program at $220^{\circ} \mathrm{C}$ oven temperature, injector temperature; $260^{\circ} \mathrm{C}$, and detector temperature; $260^{\circ} \mathrm{C}$ by flowing carrier gas $\left(\mathrm{N}_{2}\right)$ with a flow rate of $100 \mathrm{ml} / \mathrm{min}$. Split ratio was 100:1.

For the sensory analysis, eight panels familiar with mozzarella cheese were used to rank two sets of feta cheese samples $\left(0^{\circ} \mathrm{C}, 4^{\circ} \mathrm{C}\right)$ for the intensity and the preference to tastes (sweet, acidity, saltiness, bittery), flavor (milky, cow's smell, fermentation flavour) and texture (mouth feel, masticatory).

\section{Statistical Analysis}

The data from the microbiological, chemical, texture profile analysis and sensory analysis were processed with the Statistical Analysis System (Ver. 8.0 Program) (SAS, 2000). Duncan's multiple range test was applied to analyze the difference between the average of treatments at $\mathrm{p}<0.05$, $\mathrm{p}<0.01$.

\section{RESULTS \& DISCUSSION}

\section{Composition of feta cheese}

Feta cheese was made from bovine milk with a CF ratio of 0.62 , by the cheese making procedure of the Dairy Processing and Technology Center at Cheonan Yonam College. Feta cheese contains $59.87 \%$ moisture, $10.57 \%$ protein, and $56.8 \%$ FDM (fat in dry matter) with $1.47 \% \mathrm{NaCl}$ as shown in Table 3. Such compositions are similar

Table 3. Compositions of feta cheese made from bovine milk (\%)

\begin{tabular}{cccccccc}
\hline & Moisture & Fat & Protein & Ash & Salt & DM & FDM \\
\hline \hline Mean & 59.87 & 22.79 & 10.57 & 3.32 & & & \\
$\pm \mathrm{SD}$ & \pm 0.80 & \pm 6.44 & \pm 0.51 & \pm 0.42 & & 40.13 & 56.8 \\
\hline
\end{tabular}

* Mean \pm SD by triplicates. 
with those of caprine feta cheese manufactured by the same procedure (Kang \& Park, 2006), but higher in moisture and lower in protein than those $(52.9 \%$ and $16.7 \%)$ of typical compositions of Greek feta cheese made mainly from ovine milk (Anifantakis, 1991). However, the moisture content after 60 day's ripening was reported to reduce about 2\% (Georglala et al., 2005) and the total solids of the feta cheese made from ovine milk was in the ranges from 46.8 to $48.1 \%$ (Moatsou et al., 2004).

The first grade of Greek feta cheese is defined achieving a maximum moisture content less than $56 \%$ and a minimum FDM higher than 43\% (Anifantakis, 1991). The high FDM (56.7\%) of the bovine feta cheese made in this experiment reflects the low portion of casein and high fat in the raw milk. FDM of this experimental bovine feta cheese measured at $14 \mathrm{~d}$ was accord well with the result of a study by Moatsou et al. (2004), in which FDM of feta cheese made from ovine milk was $51.4 \%$ after $3 \mathrm{~d}$ for dry salting and then was increased to $55.6 \%$ at $16 \mathrm{~d}$ and was maintained at $54.8 \%$ from $30 \mathrm{~d}$ to $180 \mathrm{~d}$ of ripening. Caprine feta cheese made with a $\mathrm{C} / \mathrm{F}$ ratio of 0.64 contained 58\% FDM (Kang and Park, 2006). Pappas et al. (1994) reported that cheese milk is usually standardized to have a $\mathrm{C} / \mathrm{F}$ ratio of about $0.7 \sim 0.8$.

\section{2. $\mathrm{pH}$ and lactic acid bacteria of feta cheese}

After salting stage, the $\mathrm{pH}$ of the feta cheese was $\mathrm{pH} 6.22$ and reached to $\mathrm{pH} 5.55$ at $4{ }^{\circ} \mathrm{C}$ and $\mathrm{pH} 5.96$ at $0^{\circ} \mathrm{C}$ after $14 \mathrm{~d}$ and $\mathrm{pH} 5.25$ and $\mathrm{pH}$ 5.62 after $28 \mathrm{~d}$ ripening as shown in Table 4. The $\mathrm{pH}$ of bovine feta cheese made with mesophilic starters was almost $1 \log$ cycle lower than the result of Kandarakis et al. (2001), in which the $\mathrm{pH}$ of the curd made with thermophilic starters ranged from $\mathrm{pH} 5.28$ to 5.49. Georgala et al. (2005) reported that the $\mathrm{pH} 4.50$ at 2 month maturing should be maintained for preservation and taste. Therefore, the $\mathrm{pH} 5.25$ of bovine feta cheese at $28 \mathrm{~d}$ was somewhat higher than normal $\mathrm{pH}$ ranges of typical Greek feta cheese (Anifantakis, 1991). The $\mathrm{pH}$ of feta cheese made from ovine milk was even much lower, $\mathrm{pH} 4.50$ at $16 \mathrm{~d}$ dry salting and $\mathrm{pH} 4.38$ after aging at $4^{\circ} \mathrm{C}$ (Moatsou et al., 2004).

Lactic acid bacteria of feta cheese was 10.25 $\log \mathrm{CFU} / \mathrm{g}$ right after finishing cheese making, but decreased gradually by the storage days and rapidly to 6.92 and $7.21 \log \mathrm{CFU} / \mathrm{g}$ after $28 \mathrm{~d}$ storage. However, this was contradictory to the results obtained by Manolopoulou et al. (2003), in which the numbers of mesophilic and thermophilic LAB and NSLAB of the feta cheeses made from different dairies were all increased more than 3.0

Table 4. Changes of $\mathrm{pH}$ and the cell number of lactic acid bacteria of feta cheese made from bovine milk

\begin{tabular}{lccccccc}
\hline \multirow{2}{*}{ Indices } & $\begin{array}{c}\text { Storage } \\
\text { temp. }\end{array}$ & 1 & 7 & 14 & 21 & 28 & 32 \\
\cline { 3 - 8 } & & Mean $\pm \mathrm{SD}$ & Mean $\pm \mathrm{SD}$ & Mean $\pm \mathrm{SD}$ & Mean $\pm \mathrm{SD}$ & Mean $\pm \mathrm{SD}$ & Mean $\pm \mathrm{SD}$ \\
\hline \hline Cell No. & $0^{\circ} \mathrm{C}$ & $10.25 \pm 0.15^{\mathrm{a}}$ & $8.30 \pm 0.01^{\mathrm{b}}$ & $7.83 \pm 0.02^{\mathrm{c}}$ & $7.24 \pm 0.02^{\mathrm{d}}$ & $6.92 \pm 0.24^{\mathrm{e}}$ & $6.57 \pm 0.09^{\mathrm{f}}$ \\
$(\log \mathrm{CFU} / \mathrm{g})$ & $4^{\circ} \mathrm{C}$ & $10.26 \pm 0.00^{\mathrm{a}}$ & $8.56 \pm 0.02^{\mathrm{b}}$ & $7.95 \pm 0.07^{\mathrm{c}}$ & $7.62 \pm 0.03^{\mathrm{d}}$ & $7.21 \pm 0.03^{\mathrm{e}}$ & $6.67 \pm 0.05^{\mathrm{f}}$ \\
\hline \multirow{2}{*}{$\mathrm{pH}$} & $0^{\circ} \mathrm{C}$ & $6.22 \pm 0.01^{\mathrm{A}}$ & $6.26 \pm 0.01^{\mathrm{aB}}$ & $5.96 \pm 0.01^{\mathrm{aC}}$ & $5.60 \pm 0.00^{\mathrm{aD}}$ & $5.62 \pm 0.01^{\mathrm{aE}}$ & \\
& $4^{\circ} \mathrm{C}$ & $6.22 \pm 0.01^{\mathrm{A}}$ & $6.01 \pm 0.01^{\mathrm{bB}}$ & $5.55 \pm 0.01^{\mathrm{bC}}$ & $5.34 \pm 0.01^{\mathrm{bD}}$ & $5.25 \pm 0.01^{\mathrm{bE}}$ & \\
\hline
\end{tabular}

a,b,c,d,e,f : Different superscripts in the same column differ significantly $(\mathrm{p}<0.01)$.

A,B,C,D,E : Different superscripts in the same row differ significantly $(\mathrm{p}<0.01)$. 
$\log \mathrm{CFU} / \mathrm{g}$ during pre ripening of $18 \mathrm{~d}$ and then decreased at different levels according to the type of bacteria during ripening to $120 \mathrm{~d}$. The $\log \mathrm{CFU} / \mathrm{g}$ of thermophilic lactobacilli was reduced from 6.65 at $3 \mathrm{~d}$ to 4.28 at $60 \mathrm{~d}$ aging whereas that of NSLAB was increased from 3.59 to 8.06 during aging (Moatsou et al., 2004). However, no significant differences were found in the number of lactic acid bacteria between both the storage temperatures.

\section{Color of feta cheese}

The feta cheese made from caprine milk becomes usually more whitish because no carotenoid compounds present in the milk. The whiteness (L-value) of feta cheese made from bovine milk has also changed from 92.5 after salting to 100.1 at $14 \mathrm{~d}$ and 118.2 at $28 \mathrm{~d}$ (Fig. 1). A significant difference $(p<0.01)$ was shown in whiteness between two storage times. The redness (a-value) tended to change from green color $\left(-2.3\right.$ at $0^{\circ} \mathrm{C}$ and -2.4 at $4^{\circ} \mathrm{C}$ ) to red color (4.8 and 4.0) and the yellowness (b-value) turned from yellow color (8.1 and 8.3) to gray color $(-5.1$ and -4.3$)$ at both temperatures during 14 day's aging $(\mathrm{p}<0.01)$. A gray and greenish color regarded as a color defect, which was known to take place when producing feta cheese from bovine milk due to the overdosing with the complementary colors (Chr. Hansen A/S, 2002).

\section{Texture profile analysis of feta cheese}

The feta cheese had a hardness $21.75 \mathrm{~g}$, a fracturability $23.40 \mathrm{~g}$, an adhesiveness -115.50 , a springiness 1.01 , a cohesiveness 0.42 , a gumminess 9.22, a chewiness 9.32, and a resilience 0.02 (Table $5)$. The fracture strain $(60 \%)$ and the deformation rates $(60 \mathrm{~mm} / \mathrm{min})$ were applied for TPA in this experiment in spite of the suggestions of Wium et al. $\left(1997^{\mathrm{a}}, 1997^{\mathrm{b}}\right)$ to use the fracture strain of
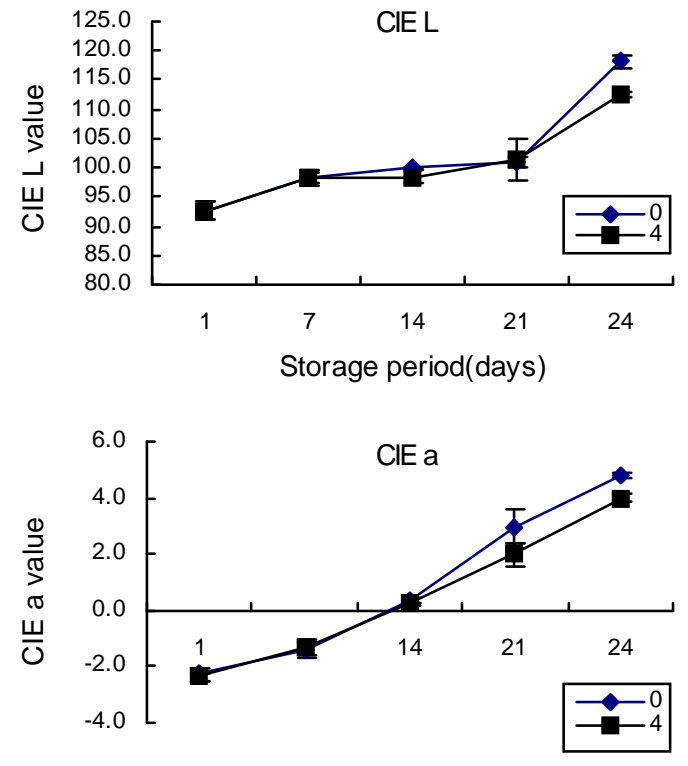

Storage period(days)

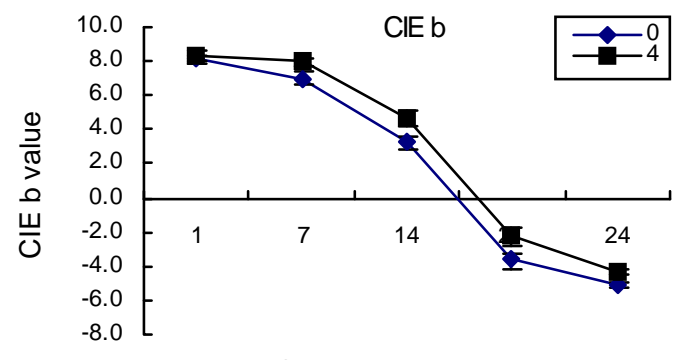

Storage period(days)

Fig. 1. Changes of CIE color of feta cheese made from bovine milk.

$25 \sim 35 \%$ order and the deformation rates of $50 \mathrm{~mm} / \mathrm{min}$ for TPA (texture profile analysis). The hardness and the fracturability were gradually increased from $21.75 \mathrm{~g}$ to $28.00 \mathrm{~g}$ and from $23.40 \mathrm{~g}$ to $29.00 \mathrm{~g}$, respectively, at the temperature of $0{ }^{\circ} \mathrm{C}$ for $14 \mathrm{~d}$. According to Moatsou et al. (2004) that the hardness and the fracturability of ovine feta cheese were $9.04 \mathrm{~kg}$ and $3.03 \mathrm{~kg}$ from 60 d-old feta cheese made with calf rennet, bovine feta cheese seemed to be much softer and weak in the texture. Adhesiveness was rapidly increased after progressing of aging at both temperatures. Springiness and cohesiveness were not changed at 
Table 5. Texture profile analysis of feta cheese made from bovine milk

\begin{tabular}{|c|c|c|c|c|c|c|c|c|c|}
\hline \multicolumn{2}{|c|}{ Aging } & \multirow[b]{2}{*}{ Hardness } & \multirow[b]{2}{*}{ Fracturability } & \multirow[b]{2}{*}{ Adhesiveness } & \multirow[b]{2}{*}{ Springiness } & \multirow[b]{2}{*}{ Cohesiveness } & \multirow[b]{2}{*}{ Gumminess } & \multirow[b]{2}{*}{ Chewiness } & \multirow[b]{2}{*}{ Resilience } \\
\hline $\begin{array}{l}\text { Perioc } \\
\text { (day) }\end{array}$ & Temp. & & & & & & & & \\
\hline \multirow{2}{*}{1} & \multirow{2}{*}{$4^{\circ} \mathrm{C}$} & 21.75 & 23.40 & $-115.50^{\mathrm{b}}$ & 1.01 & 0.42 & 9.22 & 9.32 & $0.02^{\mathrm{c}}$ \\
\hline & & \pm 0.78 & \pm 1.56 & \pm 7.78 & \pm 0.02 & \pm 0.01 & \pm 0.14 & \pm 0.15 & \pm 0.01 \\
\hline \multirow{4}{*}{7} & \multirow{2}{*}{$0^{\circ} \mathrm{C}$} & 24.91 & 24.91 & $-42.96^{\mathrm{a}}$ & 0.97 & 0.46 & 11.78 & 11.53 & $0.09^{b}$ \\
\hline & & \pm 6.71 & \pm 6.71 & \pm 34.89 & \pm 0.03 & \pm 0.08 & \pm 5.32 & \pm 5.51 & \pm 0.01 \\
\hline & \multirow{2}{*}{$4^{\circ} \mathrm{C}$} & 20.45 & 20.45 & $-14.81^{\mathrm{a}}$ & 1.02 & 0.48 & 9.73 & 9.86 & $0.11^{\mathrm{b}}$ \\
\hline & & \pm 3.10 & \pm 3.10 & \pm 0.52 & \pm 0.06 & \pm 0.01 & \pm 1.29 & \pm 0.69 & \pm 0.01 \\
\hline \multirow{4}{*}{14} & \multirow[b]{2}{*}{$0^{\circ} \mathrm{C}$} & 28.00 & 29.00 & $-1.25^{\mathrm{a}}$ & 0.99 & 0.60 & 14.40 & 17.74 & $0.18^{\mathrm{a}}$ \\
\hline & & \pm 4.24 & \pm 5.66 & \pm 0.07 & \pm 0.00 & \pm 0.21 & \pm 5.89 & \pm 10.62 & \pm 0.04 \\
\hline & \multirow{2}{*}{$4^{\circ} \mathrm{C}$} & 23.00 & 25.50 & $-0.15^{\mathrm{a}}$ & 1.04 & 0.44 & 12.91 & 12.41 & $0.20^{\mathrm{a}}$ \\
\hline & & \pm 1.41 & \pm 3.54 & \pm 0.01 & \pm 0.06 & \pm 0.02 & \pm 0.93 & \pm 1.63 & \pm 0.03 \\
\hline
\end{tabular}

$\overline{a, b, c}$ Different superscripts in the same column differ significantly $(\mathrm{p}<0.01)$.

both temperatures. Gumminess and chewiness were increased higher when aged at $0^{\circ} \mathrm{C}$ than at $4^{\circ} \mathrm{C}$, but was not shown any statistical differences. Resilience was increased significantly $(\mathrm{p}<0.01)$ throughout the aging periods.

The textural characteristics of bovine feta cheese obtained from TPA were weak in overall respects. This weak texture revealed that feta cheese with a high $\mathrm{pH}$ of curd could become softer when the curd was salted in a brine solution. However, the textural sensory attributes of feta cheese in tin can, which is packed in brine, were firm, inelastic, easy to cut, hard to spread and non sticky, but those of brick feta, which were packed without brine, were soft, elastic, easy or hard to cut and easy to spread (Wium et al. $\left(1997^{\mathrm{a}}\right)$. It is known that the traditional Greek feta cheese is brittle with small hole (Chr. Hansen A/S, 2002), but the cheese becomes rubbery when the curd texture was springy, which property is caused by a high scalding temperature, and the cheese became harder when the $\mathrm{pH}$ of the cheese curd is too low at the stages of renneting or milling (Jack and Peterson, 1992). Lactic starter bacteria, which produce high proteolytic enzyme activities, could also contribute to the texture scores by accumulating higher amounts of soluble $\mathrm{N}$ and PTA-N fractions as ripening progressed (Litopoulou et al., 1993). It could be explained by the markedly discriminative in the structure; primary (Fiat and Jolles, 1989) and tertiary structures (Ono et al., 1989), smaller size (Martin, 1993; Grosclaude, 1995) and regular shape (Remeuf and Lenoir, 1986) of the casein micelles of caprine milk.

\section{Organoleptic properties of feta cheese}

The intensities of smell, color, sweetness and saltiness of bovine feta cheese were higher than those of mozzarella cheese, but no significant difference between the both cheeses stored in different temperatures was found (Fig. 2). The organoleptic intensities in sweetness, milky taste and saltiness were enhanced at the level of $\mathrm{p}<0.01$, and masticatory texture at $\mathrm{p}<0.05$ by prolonging the aging to $14 \mathrm{~d}$. 

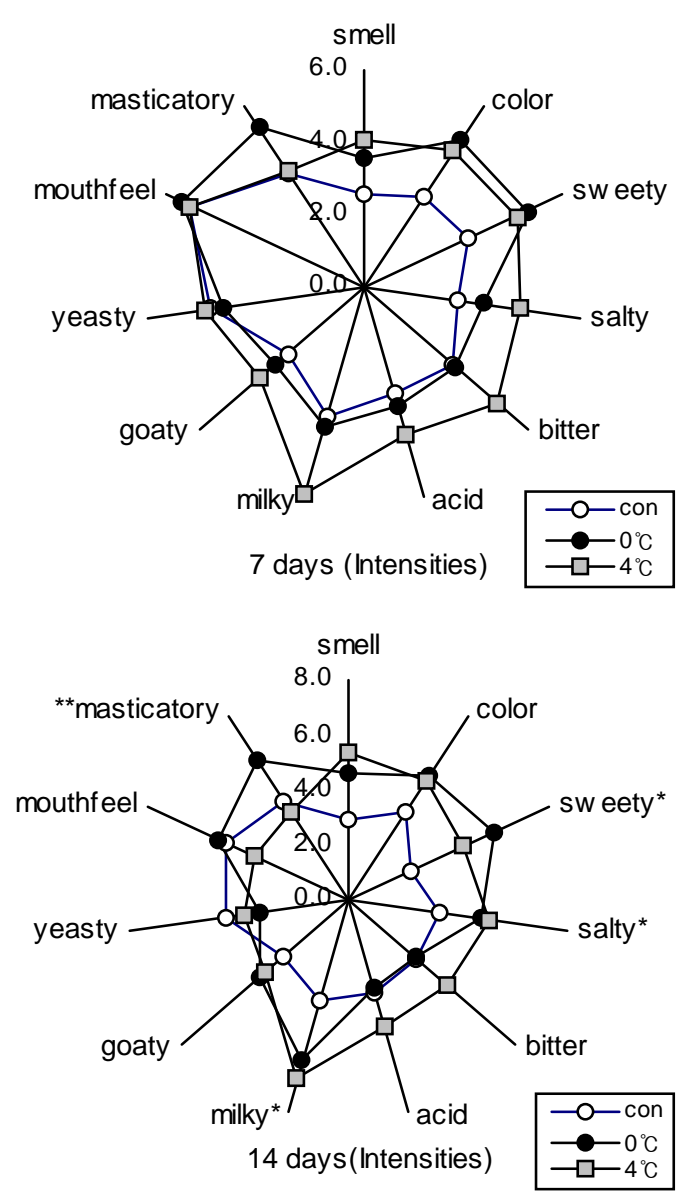

Fig. 2. Organoleptic intensities on feta cheese made from bovine milk.

The organoleptic preferences, saltiness and bitterness were more acceptable $(\mathrm{p}<0.05)$ than those of mozzarella cheese (Fig. 3). However, the overall preferences of smell, color, tastes (sweetness, acidity, milky taste), flavour (cow's smell, fermentation flavour) and texture (masticatory, mouth feel), and total organoleptic scores were similar with those of mozzarella cheese. Also total preferences for the organoleptic characteristics were improved significantly $(\mathrm{p}<0.01)$ by the prolonged aging, except smell, color, mouth feel, and masticatory texture.

When these results were comparing with the goat feta cheese by Kang and Park (2006), the intensity of milky was stronger and the preferences for saltiness and fermentation flavour were increased, along with the total scores.
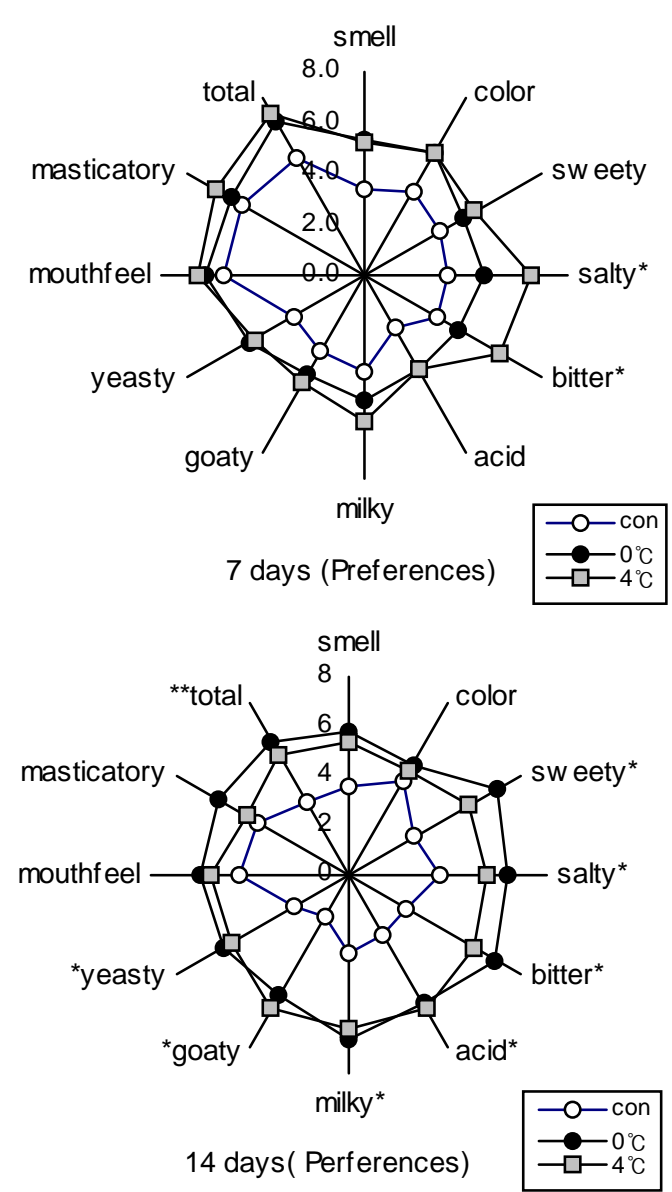

Fig. 3. Organoleptic preferences on feta cheese made from bovine milk.

\section{Fatty acid profiles of feta cheese}

As presented in Table 6, palmitic acid (c16:0) and oleic acid $(\mathrm{c} 18: \ln 9 \mathrm{c})$ are the most abundant fatty acids in feta cheese made from bovine milk and the contents of them were $27.65 \%$ and $27.69 \%$ of TFA (total fatty acids), respectively, and followed by stearic acid (c18:0) 15.85\%.

The content of SCFA (short chain fatty acids) was $1.53 \%$ of TFA of feta cheese, mainly composed with $\mathrm{c} 4: 0(0.58 \%)$, c6:0(0.42\%), c8:0(0.53\%). This portion of SCFA was higher than those of caprine feta cheese (Kang and Park, 2006), but lower than those of Greek feta cheese, in which the contents of $\mathrm{c} 4: 0, \mathrm{c} 6: 0, \mathrm{c} 8: 0$ were from 5.1 to $5.8 \%$, from 3.1 to $3.7 \%$, and from 0.0 to $0.1 \%$, 
Table 6. Fatty acid compositions of feta cheese made from bovine milk

\begin{tabular}{|c|c|c|c|}
\hline & Fatty acids & Means & $\mathrm{SD}$ \\
\hline \multirow{15}{*}{$\begin{array}{l}\text { Saturated } \\
\text { fatty acids } \\
\text { (SFA) }\end{array}$} & $\mathrm{c} 4: 0$ & 0.58 & 0.43 \\
\hline & $\mathrm{c} 6: 0$ & 0.42 & 0.43 \\
\hline & c8:0 & 0.53 & 0.12 \\
\hline & c10:0 & 1.29 & 0.27 \\
\hline & c12:0 & 0.40 & 0.49 \\
\hline & c14:0 & 7.87 & 0.75 \\
\hline & c15:0 & 0.58 & 0.28 \\
\hline & c16:0 & 23.31 & 0.69 \\
\hline & c17:0 & 1.07 & 0.91 \\
\hline & c18:0 & 12.69 & 0.56 \\
\hline & c20:0 & 0.11 & 0.01 \\
\hline & $\mathrm{c} 22: 0$ & 0.43 & 0.49 \\
\hline & c23:0 & 3.00 & 2.24 \\
\hline & c24:0 & 0.33 & 0.46 \\
\hline & $\sum \mathrm{SFA}$ & 52.61 & \\
\hline \multirow{14}{*}{$\begin{array}{l}\text { Monounsaturated } \\
\text { fatty cids } \\
\text { (MUFA) }\end{array}$} & $\mathrm{c} 10: 1$ & 0.12 & 0.03 \\
\hline & c12:1 & 0.09 & 0.00 \\
\hline & c14:1 & 0.00 & 0.00 \\
\hline & c15:1 & 1.11 & 0.68 \\
\hline & c16:1 & 1.37 & 0.16 \\
\hline & c17:1 & 0.44 & 0.02 \\
\hline & c18:1w9c & ND* & ND \\
\hline & c18:1w7c & 23.63 & 1.10 \\
\hline & c18:1c & 0.16 & 0.22 \\
\hline & c18:1t & 1.85 & 2.62 \\
\hline & c $20: \ln 9$ & 0.10 & 0.01 \\
\hline & $\mathrm{c} 22: 1$ & ND & ND \\
\hline & c24:1 & 0.11 & 0.15 \\
\hline & $\sum$ MUFA & 28.98 & \\
\hline \multirow{20}{*}{$\begin{array}{l}\text { Polyunsaturated } \\
\text { fatty acids } \\
\text { (PUFA) }\end{array}$} & $\mathrm{c} 16: 2$ & 1.58 & 1.71 \\
\hline & c20:2 & 6.64 & 9.01 \\
\hline & $\mathrm{c} 22: 2$ & 0.37 & 0.52 \\
\hline & c18:2w6cc & 0.22 & 0.31 \\
\hline & c18:2w6ct & 2.46 & 0.47 \\
\hline & c18:2w6tc & 4.15 & 5.55 \\
\hline & c18:2w6tt & 0.04 & 0.05 \\
\hline & c18:2c9t11 & 0.04 & 0.05 \\
\hline & $\mathrm{c} 18: 2 \mathrm{t} 10 \mathrm{c} 12$ & 0.07 & 0.10 \\
\hline & c18:3w6c & 0.41 & 0.11 \\
\hline & $\mathrm{c} 20: 3 \mathrm{n} 6$ & 1.69 & 0.45 \\
\hline & c20:4 & 0.19 & 0.09 \\
\hline & $\sum \omega 6$ & 9.27 & \\
\hline & c18:3w3 & 0.06 & 0.09 \\
\hline & c18:3w3t & 0.34 & 0.16 \\
\hline & $\mathrm{c} 18: 3 \mathrm{w} 3 \mathrm{c}$ & 0.03 & 0.04 \\
\hline & c20:5n3 & 0.00 & 0.00 \\
\hline & $\mathrm{c} 22: 6 \mathrm{n} 3$ & 0.12 & 0.17 \\
\hline & $\sum \omega 3$ & 0.55 & \\
\hline & $\sum$ PUFA & 18.41 & \\
\hline
\end{tabular}

$\overline{\mathrm{N}=2, * \mathrm{ND} \text { : Not detected in this analytical conditions. }}$ respectively (Zlatanos et al., 2002). The amount of FFA (free fatty acids) c4:0-c8:0 of ovine feta cheese was 1,100ppm and c12:0 was 2,167 ppm (Moatsou et al., 2004), and c2:0-c8:0 represented approximately $33 \%$ to $44 \%$ of TFA (Georgala et al., 2005). The high levels of SCFA have been known to be affected by the unexpected lipolytic enzyme action of rennet on cheese fat, which results in the goaty taste and leads to stronger bitterness and saltiness (Nelson et al., 1997; Alonso et al., 1999) and a matured cheese taste (Georgala et al., 1995).

The fatty acids in feta cheese was mainly composed of c18:1w7c (23.63\%), c16:0 (23.31\%), c18:0 (12.69\%) and c14:0 (7.87\%). Abundance of LCFA (long chain fatty acid) was established well by Zlatanos et al. (2002), but c16:0 (21.4\%) was the highest and followed by the order of $\mathrm{c} 18: 1 \mathrm{n} 9 \mathrm{c}$ (14.18\%). Evolution of lipolysis during the ripening resulted in the highest portion of $\mathrm{c} 4: 0$, followed by c10:0 and c12:0 as FFA of ripened ovine/caprine feta cheese (Georgala et al., 2005).

The content of SFA (saturated fatty acids) $52.61 \%$ are higher than that of USFA (unsaturated fatty acids) $47.39 \%$ of TFA (Table 7). Although the ratio of USFA was higher than SFA, the portion of USFA was much lower than in Greek feta cheese. The contents of cis- MUFA $23.80 \%$ and trans-MUFA $1.85 \%$ were consent well with the results of Zlatanos et al., 2002), but cisPUFA $0.66 \%$ and trans- PUFA $0.38 \%$ were lower. According to the number of double bonds of USFA, mono-enoic acids (28.98\%) and di-enoic acid (15.57\%) were the main components and tri-enoic acids $(2.53 \%)$ and poly-enoic acid $(0.11 \%)$ were minor components of the USFA. These compositions of USFA obviously differ from those of caprine feta cheese ranked di-enoic acid as a major component (Kang \& Park, 2006). Two isomers (c18:2c9t11 and c18:2t10c12) of CLA (conjugated linoleic acid) in feta cheese was $0.12 \%$ of TFA, but was lower than $1.9 \%$ of 
CLA in Greek feta cheese (Zlatanos et al., 2002) and $0.36 \%$ in caprine feta cheese (Kang \& Park, 2006). Total contents of $\omega 6$ and $\omega 3$ fatty acids were $9.27 \%$ and $0.55 \%$, respectively. Among $\omega 3$ fatty acids, arachidonic acid $(0.19 \%)$ was detected to be present in bovine feta cheese, but DHA $(0.12 \%)$ was lower than that $(0.26 \%)$ of caprine feta cheese.

Table 7. Fatty acid profiles of feta cheese made from bovine milk (\%/TFA)

\begin{tabular}{lccc}
\hline Fatty acids & $\begin{array}{c}\text { Bovine } \\
\text { feta cheese }\end{array}$ & $\begin{array}{c}\text { Caprine* } \\
\text { feta cheese }\end{array}$ & $\begin{array}{c}\text { Feta } \\
\text { cheese** }\end{array}$ \\
\hline \hline SFA & 52.61 & 46.73 & 70.2 \\
UFA & 47.39 & 43.06 & 28.8 \\
cis-MUFA & 23.80 & 12.80 & 17.5 \\
trans-MUFA & 1.85 & 13.08 & 3.5 \\
cis-PUFA & 0.66 & 2.83 & 3.5 \\
trans-PUFA & 0.38 & 0.24 & 1.2 \\
\hline
\end{tabular}

SFA : Saturated fatty acids,

MUFA : Monounsaturated fatty acids,

PUFA : Polyunsaturated fatty acids,

*Data of Kang and Park(2006).

**Data of Zlatanos et. al, (2002).

\section{ABSTRACT}

Fatty acid compositions and physicochemical properties of feta cheese made from bovine milk were studied. Nutritional compositions of feta cheese were fat $22.79 \%$, protein $10.57 \%$ with moisture content of $59.87 \%$. The $\log \mathrm{cfu} / \mathrm{g}$ of lactic acid bacteria in bovine feta cheese decreased from 10.25 to 7.95 and $\mathrm{pH}$ also changed from $\mathrm{pH} 6.22$ to $\mathrm{pH} 5.55$ during storage at $4^{\circ} \mathrm{C}$ for 14 $\mathrm{d}$ aging. The color of feta cheese turned into more whitish (L-value, 100.1) with a red (a-value, 4.6) and gray (b-value, -4.1) color after 14 day's aging. For the texture profile analysis of bovine feta cheese, resilience was increased significantly $(p<0.01)$ throughout the aging periods and adhesiveness was rapidly increased right after progressing of aging at both temperatures, but no difference was found between the aging periods. Hardness, fracturability, gumminess and chewiness were gradually increased at $0^{\circ} \mathrm{C}$, but no statistical significances were found. Springiness and cohesiveness were not changed at both temperatures. In organoleptic evaluations, organoleptic intensities in sweetness, milky taste and saltiness were significantly enhanced over those of the control cheese at the level of $\mathrm{p}<0.01$, and masticatory texture at $\mathrm{p}<0.05$ with the progress of aging to $14 \mathrm{~d}$. Organoleptic preferences were significantly $(p<0.01)$ enhanced except smell, color, mouth feel, and masticatory texture with the aging. In the fatty acid compositions of feta cheese analyzed by gas chromatography, the content of SFA (52.61\%) was slight higher than that of USFA (47.39\%) composed with MUFA (28.98\%) and PUFA (18.41\%). Among the nutritionally important fatty acids; $\omega 6(9.27 \%)$ and $\omega 3(0.55 \%)$ fatty acids, CLA (0.12\%), arachidonic acid (0.19\%) and DHA $(0.12 \%)$ were also found in bovine feta cheese.

(Key words : Feta cheese, Nutritional compositions, Organoleptic evaluations, Textural properties, Fatty acid compositions).

\section{ACKNOWLEDGEMENT}

This study was conducted by the financial support from the program for Agro business 2005 of the Chungnam Agricultural Techno Park (CATP). The author wants to express his gratitude to Dr. S. N. Kang and Mr. Y. K. Park for their technical assistance to this experiment.

\section{REFERENCES}

1. Anifantakis, E. M. 1991. Greek cheese. National Dairy Committe of Greece. Athens. 
2. Alonso, L., Fontecha, J., Lozada, L., Fraga, M. J. and Juarez, M. 1999. Fatty acid composition of caprine milk: major, branch chain and trans fatty acids. J. Dairy Sci. 82:878-884.

3. A.O.A.C. 1990. Official Methods of Analysis. 15th edn. Association of Official Analytical Chemists, Washington D.C. USA.

4. Bintsis, T. and Robinson, R. K. 2004. A study of the effects of adjunct cultures on the aroma compounds of feta type cheese. Food Chem. 88:435-411.

5. CHR. HANSEN A/S. 2002. Guideline of Feta cheese. In: Chr. Hansen's Brochure. Horsholm, Denmark. p. 1-24.

6. Fiat, A. M. and Jolles, P. 1989. Caseins of various origins and biologically active casein peptides and oligosaccharides: Structural and physiological aspects. Mol. and Cell. Biochem. 87:5-30.

7. Fox, P. F., Guinee, T. P., Cogan, T. M. and McSweeney, P. L. H. 2000. Fundamentals of Cheese Science. Aspen Publ. Co., U.S.A.

8. Georgala, A. K., Kandarakis, I. G., Kaminarides, S. E. and Anifanakis, E. M. 1999. Volatile free fatty acid content of feta and white brined cheeses. Australian J. of Dairy Technol. 54:5-8

9. Georgala, A., Moschopoulou, E., Aktypis, A., Massouras, T., Zoidou, E., Kandarakis, I. G. and Anifantakis, E. M. 2005. Evolution of lipolysis during the ripening of traditional feta cheese. Food Chem. 93(1):73-80.

10. Grosclaude, F. 1995. Genetic polymorphisms of milk proteins. In : Proceedings of the IDF Seminar on Implications of Genetic Polymorphism of Milk Proteins on Production and Processing of Milk. Zurich, Switzerland, vol. 3. Internat. Dairy Fed. Publ., Brussels, Belgium, pp. 28-29.

11. Haenlein, G. F. W. and Caccese, R. 1984. Goat milk versus cow milk. In : Extension Goat Handbook. (Ed. Haenlein, G. F. W and Ace, D. L.) USDA Publ. Washington D.C. E 1. p 1-4.

12. Jack, F. R. and Peterson, A. 1992. Texture of hard cheese. Trends in Food Sci. and Technol.,
3:160-164.

13. Kandarakis, I., Moatsou, G., Georgala, A. I. K., Kaminarides, S. and Anifantakis, E. 2001. Effect of draining temperature on the biochemical characteristics of feta cheese. Food Chem. 72:369378.

14. Kang, S. N. and Park, S. Y. 2006. Physicochemical and organoleptic properties of feta cheese made from goat milk. J. Anim. Sci. \& Technol. (Kor.). 48(2):293-306.

15. Katsiari, M. C., Voutsinas, L. P., Kondyli, E. and Alichanidis, E. 2002. Flavour enhancement of low-fat feta type cheese using a commercial adjunct culture. Food Chem. 79(2):193-198.

16. Kim, H. J. and Park, Y. K. 2004. A study on the biochemical and physiological properties of goat milk by the goat species. 2004 Cheonan Yonam IACF Report. pp. 65-104.

17. Kim, S. K. and Hur, K. C. 2001. A study of cheese making for Korean type using goat milk. Daesan Nonchong. 8:421-431.

18. Kondyli, E., Katsiari, M. C., Masouras, T. and Voutsinas, L. P. 2002. Free fatty acids and volatile compounds of low fat feta type cheese made with a commercial adjunct culture. Food. Chem. 79(2):199-205.

19. Litopoulou, T. E., Tzabetakis, N. and Vafopoulou, M. A. 1993. Effect of the type of lactic starter on microbiological chemical and sensory characteristics of feta cheese. Food Microbiol. 10(1):31-41.

20. Manopoulou, E., Sarantinopoulos, P., Zoidou, E., Aktypis, A., Moschopoulou, E., Kandarakis, I. G. and Anifantakis, E. M.. 2003. Evolution of microbial populations during traditional feta cheese manufacture and ripening. Int. J. Food Microbiol. 82(2):153-161.

21. Martin, P. 1993. Polymorphisme genetique des lactoproteines caprines. Lait. 73:511-532.

22. Moatsou, G., Moschopoulou, E., Georgala, A., Zoidou, E., Kandarakis, I., Kaminarides, S. and Anifantakis, E. 2004. Effect of artisanal liquid rennet from kids and lambs abomasa on the 
characteristics of feta cheese. Food Chem. 88:517-525.

23. Nelson, J. H., Jesen, R. G. and Pitas, R. E. 1997. Pregastric esterases and other oral lipases, A review J. Dairy Sci. 60(3):327-362.

24. Ono, T., Kohno, H., Odagiri, S. and Takagi, T. 1989. Subunit components of casein micelles from bovine, ovine, caprine and equine milk. J. Dairy Res. 56:61-68.

25. Pappas, S. P., Kondyli, E., Voutsinas, L. P. and Mallatou, H. 1994. Effect of standardization of ewes' milk for casein/fat ratio on the composition, sensory and rheological properties of feta cheese. Int. Dairy J. 4(8):763-778.

26. Park, S. Y. and Kim, C. Y. 2006. Prospects for consumption of dairy goat milk products. In : Proceedings of the Kor. Dairy Technol. and Sci. 62'th Symposium, Seoul, Korea. pp. 59-69.

27. Park, Y. W. 2000. Hypo-allergenic and therapeutic significance of goat milk. Food Sci. and Industry. 34(4):6-12.

28. Remeuf, F. and Lenoir, J. 1986. Relationships between the physicochemical characteristics of goat's milk and its rennetability. Bull. IDF Doc. No. 202. Brussels. 68-72.

29. Robinson, R. K. 1995. A color guide to cheese and fermented milks. Chapman \& Hall. New York. p.83-87.
30. Sarantinopoulos, P., Karantzopoulos, G. and Tsakalidou, E. 2002. Effect of Enterococcus faecium on microbiological, physicochemical and sensory characteristics of Greek feta cheese. Int. J. Food Microbiol. 76(1-2):93-105.

31. SAS Institute Inc. 2000. SAS User's Guide: Statistics. Version 8.0. SAS Institute, Cary, North Carolina.

32. Wium, H. and Qvist, K. B. $1997^{\mathrm{a}}$. Rheological properties of feta cheese determined by uniaxial compression and dynamic testing. J. of Texture Studies. 28:435-454.

33. Wium, H., Gross, M. and Qvist, K. B. $1997^{\mathrm{b}}$. Uniaxial compression of UF feta cheese related to a sensory texture analysis. J. of Texture Studies. 28:454-476.

34. Wium, H., Pederson, P. S. and Qvist, K. B. 2003. Effect of coagulation conditions on the microstructure and the large deformation properties of fat-free feta cheese made from ultrafiltered milk. Food Hydrocolloids. 17(3):287-296.

35. Zlatanos, S., Laskaridis, K., Feist, C. and Sagredos, A. 2002. CLA content and fatty acid composition of Greek feta cheese and hard cheese. Food Chem. 78(4) 471-477.

(접수일자 : 2006. 7. 19. / 채택일자 : 2006. 8. 22.) 